\title{
Reconstruction of the annual balance of Vadret da Morteratsch, Switzerland, since 1865
}

\author{
Johanna NEMEC, ${ }^{1}$ Philippe HUYBRECHTS, ${ }^{1,2}$ Oleg RYBAK, ${ }^{1,3}$ Johannes OERLEMANS ${ }^{4}$ \\ ${ }^{1}$ Departement Geografie, Vrije Universiteit Brussel, Pleinlaan 2, B-1050 Brussels, Belgium \\ E-mail: jnemec@vub.ac.be \\ ${ }^{2}$ Alfred-Wegener-Institut für Polar- und Meeresforschung, Postfach 120161, D-27515 Bremerhaven, Germany \\ ${ }^{3}$ Scientific Research Centre, Russian Academy of Sciences, Teatralnaya 8-a, 354000 Sochi, Russia \\ ${ }^{4}$ Instituut voor Marien en Atmosferisch Onderzoek, Universiteit Utrecht, Princetonplein 5, 3584 CC Utrecht, The Netherlands
}

\begin{abstract}
We have reconstructed the annual balance of Vadret da Morteratsch, Engadine, Switzerland, with a two-dimensional energy-balance model for the period 1865-2005. The model takes into account a parameterization of the surface energy fluxes, an albedo that decreases exponentially with snow depth as well as the shading effect of the surrounding mountains. The model was first calibrated with a 5 year record of annual balance measurements made at 20 different sites on the glacier between 2001 and 2006 using meteorological data from surrounding weather stations as input. To force the model for the period starting in 1865 , we employed monthly temperature and precipitation records from nearby valley stations. The model reproduces the observed annual balance reasonably well, except for the lower part during the warmest years. Most crucial to the results is the altitudinal precipitation gradient, but this factor is hard to quantify from the limited precipitation data at high elevations. The simulation shows an almost continuous mass loss since 1865, with short interruptions around 1920, 1935 and 1980. A trend towards a more negative annual balance can be observed since the beginning of the 1980s. The simulated cumulative mass balance for the entire period 1865-2005 was found to be $-46 \mathrm{~m}$ w.e.
\end{abstract}

\section{INTRODUCTION}

Global warming and other ongoing changes in the Earth system are beginning to have significant impacts, not only on the physical environment, but also on the biosphere and society (Dyurgerov and Meier, 2005). Glacier and ice-cap variations are among the most visible indications of the effects of climate change (Lemke and others, 2007). This is mainly due to the clearly recognizable retreat of many large valley glaciers in response to a temperature increase of about $1 \mathrm{~K}$ since 1850 , which is hardly noticeable otherwise (Paul and others, 2007). Such glacier retreats have direct impacts on processes of global importance such as sea-level rise, the hydrology of mountain-fed rivers, the freshwater balance of the oceans, natural disasters, and even the shape and rotation of the Earth (Dyurgerov and Meier, 2005). To make a reliable prediction on how glaciers may behave in the future, it is important to understand how glaciers reacted to climate variability in the past.

At present, the total glacier area outside Greenland and Antarctica is estimated to be $(522 \pm 42) \times 10^{3} \mathrm{~km}^{2}$ (Raper and Braithwaite, 2005). Estimates of glacier and ice-cap volume are more difficult to establish, and vary between 15 and $37 \mathrm{~cm}$ of global sea-level equivalent (Lemke and others, 2007). Glaciers in the European Alps only constitute a very small fraction of this. However, in common with many other mountain glaciers worldwide, most Alpine glaciers reached their last maximum extent between 1850 and 1900 at the end of the Little Ice Age, and retreated to near their minimum extent over at least the last several thousand years after that. A combination of in situ measurements, remote sensing and numerical modeling shows that glaciers in the European Alps lost 35\% of their total area from 1850 until the 1970s, and almost 50\% by 2000 (Zemp and others,
2006). This trend is confirmed by the new satellite-derived Swiss glacier inventory, which revealed that mean glacier area loss per decade from 1985 to 1998/99 has accelerated by a factor of seven compared to the period 1850-1973 (Paul and others, 2007).

Central to studies of glacier changes is the mass balance. For the last decades of the 20th century, there is a strong negative correlation between Northern Hemispheric net mass balances and Northern Hemispheric summer temperatures (Greene, 2005). Changes in the snow accumulation also matter, and may have dominated in responses to large circulation changes or when temperature is not changing greatly (Lemke and others, 2007). For example, analysis of glacier mass balance, volume change, length fluctuations and homogenized temperature records for the western part of the European Alps indicates a significant effect of precipitation changes on glacier variations during the 18th and 19th centuries (Vincent and others, 2005).

Direct measurements of mass balance are available for only a limited number of glaciers and seldom extend far back in time. Therefore, models have to be used to extend measured mass-balance series in the future and the past. Several approaches can be used such as temperature-index models, regression models and energy-balance models (Hock, 2005). For instance, with a simple regression model, Greene and others (1999) found an upward shift of the equilibrium-line altitude (ELA) of $114 \mathrm{~m}$ between 1850 and 1973 for the Swiss Alps. Schöner and Böhm (2007) applied a linear regression model on two Austrian glaciers (Hintereisferner and Vernagtferner) to reconstruct the mass balance back to 1800 . Vincent (2002) used a degree-day model to reconstruct the mass balance of four French glaciers (SaintSorlin, Gébroulaz, Argentière and Mer de Glace) over the 20th century. More recently, a more complex distributed 


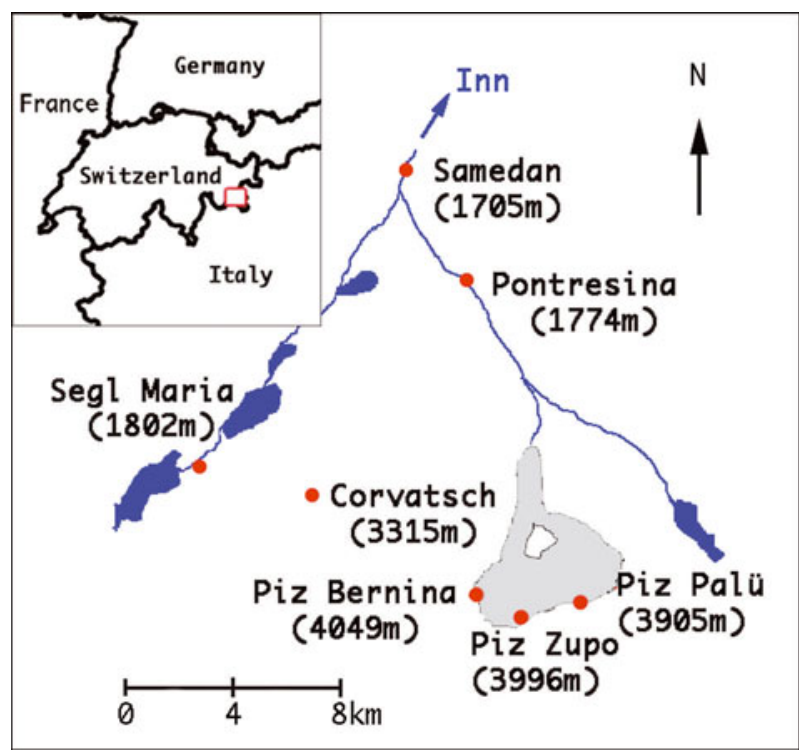

Fig. 1. Location map of Vadret da Morteratsch and its surroundings in the Engadine, southeast Switzerland. The glacier area is shown in grey in the inset. Lakes and rivers are indicated in blue.

temperature-index melt model coupled to an accumulation model was used to reconstruct the seasonal mass balance of four Alpine glaciers (Aletschgletscher, Rhonegletscher, Griesgletscher and Silvrettagletscher) for the period 18652006 (Huss and others, 2008).

In this paper, we focus on the evolution of the annual mass balance of Vadret da Morteratsch. The annual balance is defined as the change in mass, expressed in water equivalent, on a fixed date relative to the same date in the previous year (Anonymous, 1969; Paterson, 1994). Vadret da Morteratsch is located in the Bernina Massif in southeast Switzerland and is the largest glacier in this area. A map of the area around Vadret da Morteratsch is shown in Figure 1. A range of high mountains, such as Piz Palü, Piz Zupo and Piz Bernina, surrounds the glacier. Piz Bernina (4049 ma.s.l.), which is located in the southwest of the glacier, represents the highest point of the glacier. The glacier tongue flows down to approximately $2030 \mathrm{~m}$ (status in 2006). At present, Vadret da Morteratsch has a length of about $7 \mathrm{~km}$ and an estimated area of $16 \mathrm{~km}^{2}$; at a distance of about $2 \mathrm{~km}$ from the snout, Vadret Pers flows into Vadret da Morteratsch from the east. According to length measurements, Vadret da Morteratsch reached its maximum extent in 1857 and shortened by $2196 \mathrm{~m}$ between 1878 and 2007 (Glaciological reports, 1881-2008; Maisch and others, 1999).

We have reconstructed the annual balance of Vadret da Morteratsch with a two-dimensional energy-balance model (Oerlemans, 2001) for the period 1865-2005. A similar energy-balance model was used by Machguth (2003) to compare modeled and simulated mass balances of 14 Swiss glaciers in 2002 and to reconstruct the mass balance for Claridenfirn, Switzerland, for the period 1981-2002, using global radiation, precipitation and air temperature as input (Machguth and others, 2006). A more detailed energybalance model, using air temperature, humidity, air pressure, incoming shortwave radiation and precipitation as input, was previously applied to Vadret da Morteratsch for the period 1980-2002 (Klok and Oerlemans, 2002; Klok, 2004). In contrast to these studies, we reconstructed the surface mass balance for a longer period, starting in 1865 .

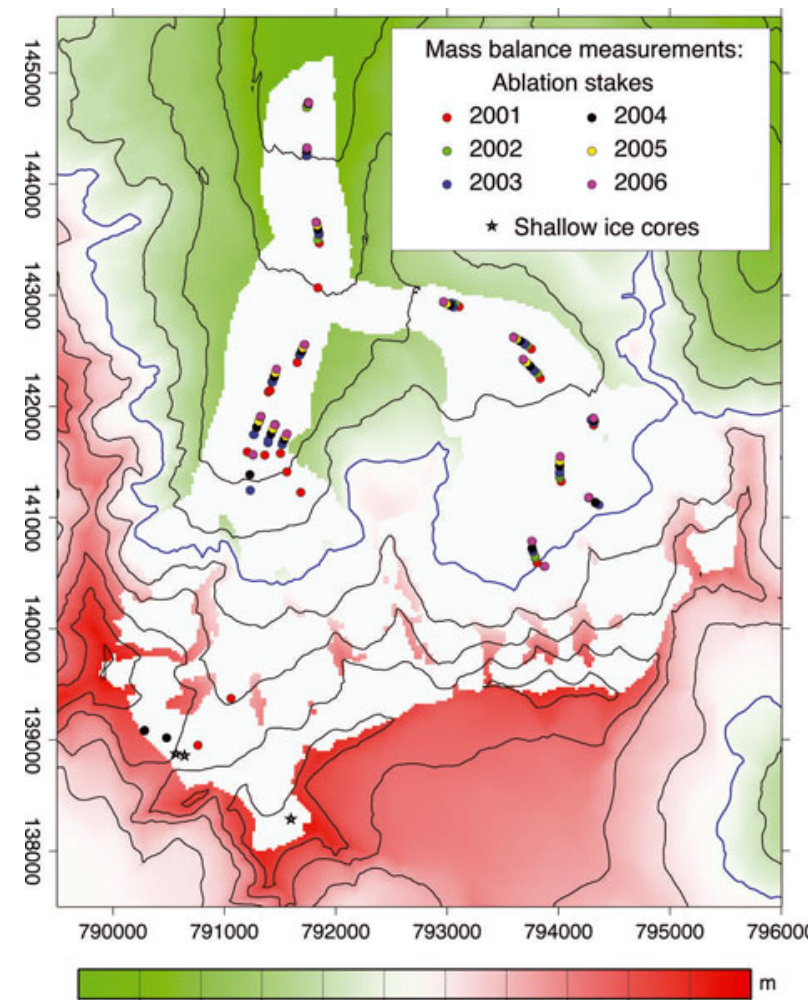
$20002200240026002800 \begin{gathered}3000320034003600 \quad 3800 \quad 4000 \quad 4200 \\ \text { Elevation }\end{gathered}$

Fig. 2. Mask of Vadret da Morteratsch, together with the topography of the surrounding area and the position of all mass-balance measurements used in this study. The map coordinates are in metres from the Swisstopo coordinate system. The blue contour line is at $3000 \mathrm{~m}$ and is close to the ELA of recent years.

This restricts the model input to precipitation and air temperature, which are the only available climate records for this longer period. The resulting cumulative mass balance is expected to be a good estimate of the total mass loss of Vadret da Morteratsch since its Little Ice Age maximum.

\section{FIELD MEASUREMENTS}

Mass-balance measurements have been carried out at about 20 different positions on both Vadret da Morteratsch and Vadret Pers by research groups of the Alfred Wegener Institute and Vrije Universiteit Brussel since 2001. The highest measurements were made from aluminium poles and snow pits in a zone around the Fuorcla Crast'Agüzza (between Piz Bernina and Piz Zupo) at 3400-3700 ma.s.I. (Fig. 2). Due to the high wind speeds in the pass area, these measurements are, however, not believed to be representative for the whole accumulation zone. These accumulation measurements were further supplemented by shallow icecore drillings in the Crast'Agüzza saddle area in October 2002 and by a $43 \mathrm{~m}$ ice core drilled by a Swiss group below Piz Zupo at 3900 ma.s.l. in March 2002 (Palmer and others, 2003). The latter ice core is believed to span a period of 11 balance years. All other measurements were carried out in the ablation area and close to the equilibrium line by classical ablation stakes. The highest of these measuring sites is close to the equilibrium line at about $3000 \mathrm{~m}$ a.s.l., and the lowest is located close to the glacier snout at about $2110 \mathrm{~m}$ a.s.l. (elevation in 2001, but down to below $2050 \mathrm{~m}$ 


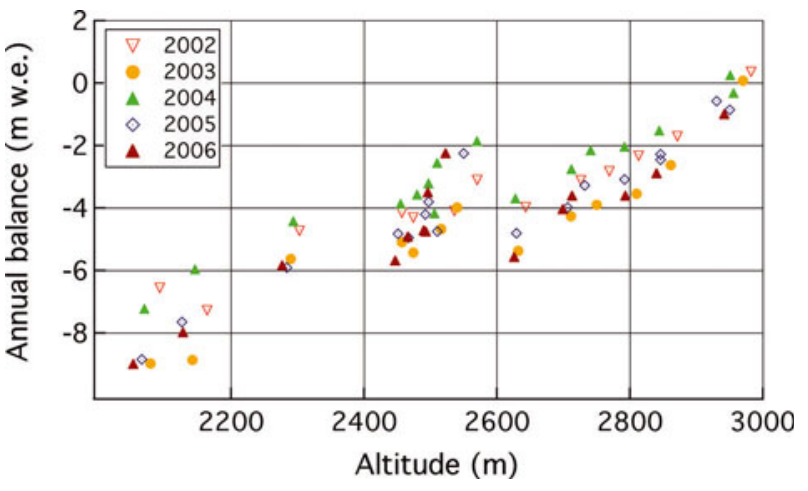

Fig. 3. Mass-balance measurements from 2002 to 2006 in the ablation zone plotted against altitude. The sites lower than 2600 ma.s.l. are located on Vadret da Morteratsch and the higher ones on Vadret Pers.

in 2007). The intermediate stakes are spread out over the ablation zone of both glaciers at an elevation interval of approximately $100 \mathrm{~m}$. Additionally, three measurements were carried out along a transect across Vadret da Morteratsch at approximately 2550 ma.s.I. to investigate the influence of shading by the surrounding mountains. Figure 2 shows the positions of the mass-balance measurements during the period 2001-06. These locations at the same time record the glacier movement over this period. Stake heights were measured at the end of the summer ablation season, usually during the first 2 weeks of October.

Figure 3 shows the annual balance measured at the stakes in the ablation zone, with the annual balance plotted against the altitude of the measurement site. The measurement sites higher than 2650 ma.s.I. are located on Vadret Pers, and those lower than $2650 \mathrm{~m}$ a.s.I. on Vadret da Morteratsch. Of these five years of measurements, 2003 was the year with the highest ablation and 2004 the year with the lowest. The mean difference in ablation between these two years is about $2 \mathrm{~m}$ w.e., less at higher elevations and somewhat more at lower elevations, i.e. the balance gradient is steepest in the warmest year. The highest ablation measured in this record was nevertheless in 2006, with $9 \mathrm{mw}$.e. at 2053 ma.s.l., in part because of the continuous glacier thinning at this site and the resulting altitude-temperature feedback. In general, the mass-balance gradient along the centre line on Vadret Pers is larger than that of Vadret da Morteratsch, probably due to the shading effects of the surrounding mountains and the different orientation of the surface with respect to the sun. This effect is also very evident when looking at the large difference in ablation between the highest measurement sites on Vadret da Morteratsch and the lowest on Vadret Pers. Ablation is up to $3 \mathrm{~m}$ w.e. larger on Vadret Pers at an altitude that is nevertheless $100 \mathrm{~m}$ higher than the corresponding site on Vadret da Morteratsch. The shading effect is also very obvious at the measurement sites at $2530 \mathrm{~m}$ a.s.I. on Vadret da Morteratsch, which correspond to the lateral cross-profile on Vadret da Morteratsch (Fig. 2). The easternmost site at the margin in, for example, 2003 experienced almost $2 \mathrm{~m}$ w.e. less melting than the stake in the middle of the glacier at approximately the same altitude. This again can be explained by the shading effects of the surrounding mountains. Note, however, that variations in albedo can also have a large effect.
Table 1. List of variables and constants used in the model

\begin{tabular}{|c|c|c|c|}
\hline Symbol & Description & Value & Unit \\
\hline$a$ & Solar azimuth angle & & $\circ$ \\
\hline$B$ & Cumulative mass balance & & mw.e. \\
\hline$c_{0}$ & $\begin{array}{l}\text { Tuning parameter in energy } \\
\text { flux parameterization }\end{array}$ & -45 & $\mathrm{~W} \mathrm{~m}^{-2}$ \\
\hline$c_{1}$ & $\begin{array}{l}\text { Tuning parameter in energy } \\
\text { flux parameterization }\end{array}$ & 12 & $\mathrm{~W} \mathrm{~m}^{-2}{ }^{\circ} \mathrm{C}^{-1}$ \\
\hline$d$ & Snow depth & & m w.e. \\
\hline$d^{*}$ & Characteristic snow depth & 0.011 & m w.e. \\
\hline$f_{\text {dif }}$ & Fraction of diffuse radiation & 0.4 & \\
\hline$f_{\text {dir }}$ & Fraction of direct radiation & 0.6 & \\
\hline$h_{\mathrm{s}}$ & Solar elevation & & $\circ$ \\
\hline$L_{\mathrm{m}}$ & Latent heat of melting & $3.34 \times 10^{5}$ & $\mathrm{Jgg}^{-1}$ \\
\hline$P$ & Precipitation sum & & mm w.e. \\
\hline$P_{\mathrm{SEG} / \mathrm{PON}}$ & $\begin{array}{c}\text { Monthly precipitation sums } \\
\text { in Segl Maria/Pontresina }\end{array}$ & & mm w.e. \\
\hline$P_{\text {solid }}$ & Solid precipitation & & mw.e. \\
\hline$Q$ & Incoming solar radiation & & $W m^{-2}$ \\
\hline$Q_{\text {dif }}$ & Diffuse solar radiation & & $W m^{-2}$ \\
\hline$Q_{\text {dir }}$ & Direct solar radiation & & $W m^{-2}$ \\
\hline$S$ & Solar constant & 1372 & $W m^{-2}$ \\
\hline$t$ & Time & & hour \\
\hline$T_{\text {air }}$ & Air temperature & & ${ }^{\circ} \mathrm{C}$ \\
\hline$T_{\text {amp }}$ & Daily temperature amplitude & 2 & ${ }^{\circ} \mathrm{C}$ \\
\hline$T_{\mathrm{COR} / \mathrm{SAM}}$ & $\begin{array}{l}\text { Monthly air temperature at } \\
\text { Corvatsch/Samedan }\end{array}$ & & ${ }^{\circ} \mathrm{C}$ \\
\hline$\alpha$ & Albedo & & \\
\hline$\alpha_{\text {ice }}$ & Albedo of ice & 0.37 & \\
\hline$\alpha_{\text {snow }}$ & Albedo of snow & 0.78 & \\
\hline$\Delta h_{\mathrm{P}}$ & $\begin{array}{l}\text { Elevation difference with } \\
\text { respect to Pontresina }\end{array}$ & & $\mathrm{m}$ \\
\hline$\Delta h_{\mathrm{T}}$ & $\begin{array}{l}\text { Elevation difference with } \\
\text { respect to Corvatsch }\end{array}$ & & $\mathrm{m}$ \\
\hline$\Delta t$ & Time-step & 1 & hour \\
\hline$\gamma P$ & $\begin{array}{l}\text { Altitudinal precipitation } \\
\text { gradient }\end{array}$ & 1.0 & mm w.e. $\mathrm{m}^{-1}$ \\
\hline$\gamma T$ & $\begin{array}{l}\text { Vertical temperature lapse } \\
\text { rate }\end{array}$ & -0.007 & $\mathrm{~K} \mathrm{~m}^{-1}$ \\
\hline$\theta$ & Glacier aspect & & $\circ$ \\
\hline$\rho$ & Water density & 1000 & $\mathrm{~kg} \mathrm{~m}^{-3}$ \\
\hline$\tau$ & Atmospheric transmissivity & 0.45 & \\
\hline$\phi$ & Glacier slope & & \\
\hline$\psi$ & Surface energy flux & & $W m^{-2}$ \\
\hline
\end{tabular}

\section{DESCRIPTION OF THE MODEL}

We used a time-dependent two-dimensional mass-balance model based on parameterizations for the surface energy fluxes and the evolution of surface albedo (Oerlemans, 2001). The inputs for this model are: (1) a gridded digital elevation model (DEM) of 1998 containing the elevation of the glacier and the surrounding mountains as provided by the Bundesamt für Landestopographie of Switzerland on a horizontal resolution of $25 \mathrm{~m}$, (2) a glacier mask containing information about form, location and size of the glacier, and (3) time series of temperature and precipitation to force the model. The variables and parameters appearing in the various formulations below are listed in Table 1 (and are not explained directly in the text).

The model is based on an equation for the cumulative mass balance $B$, which represents the gain or loss of mass at an individual gridpoint at time $t$. The time-step $\Delta t$ is 1 hour:

$$
B(t+1)=B(t)+\Delta t\left\{\min \left(0,-\frac{\psi}{L_{\mathrm{m}} \rho}\right)\right\}+P_{\text {solid }}(t) .
$$


The term $\min \left(0,-\psi / L_{\mathrm{m}} \rho\right)$ represents melting at the surface (ablation) in case of a positive surface energy flux. Sublimation is neglected, due to the very high latent heat of sublimation compared to the latent heat of melt $\left(2.834 \times 10^{6} \mathrm{~J} \mathrm{~kg}^{-1}\right.$ compared to $\left.3.334 \times 10^{5} \mathrm{~J} \mathrm{~kg}^{-1}\right)$. It is assumed that solid precipitation (snow) occurs for air temperatures below $2^{\circ} \mathrm{C}$ (accumulation).

To calculate the budget of the energy fluxes at the glacier surface, representations are required for incoming and outgoing shortwave and longwave radiation, turbulent heat fluxes and the heat flux supplied by rain. Since most of the parameters describing these fluxes are unknown or not readily available, it is more convenient to parameterize the net energy flux at the surface as:

$$
\psi=(1-\alpha) \cdot Q+c_{0}+c_{1} \cdot T_{\text {air }}
$$

where the first term on the right-hand side is the incoming radiation at the glacier surface and the term $c_{0}+c_{1} \cdot T_{\text {air }}$ is the sum of the longwave radiation balance and turbulent heat exchange (Oerlemans, 2001; cf. Table 1).

The albedo parameterization distinguishes between ice and snow following the work of Oerlemans and Knap (1998). The albedo ranges between 0.78 (typical value for snow) and 0.37 (typical value for ice) and is made to decrease exponentially with the snow depth. $d^{*}$ is the characteristic length scale for snow depth $(11 \mathrm{~mm}$ w.e.). We estimated $d^{*}$ by multiplying the depth scale found by Oerlemans and Knap (1998) by a snow density of $350 \mathrm{~kg} \mathrm{~m}^{-3}$ (Klok and Oerlemans, 2002).

$$
\alpha=\alpha_{\text {snow }}+\left(\alpha_{\text {ice }}-\alpha_{\text {snow }}\right) \exp \left(-d / d^{*}\right) .
$$

The incoming solar radiation $Q$ is split up into a direct and a diffuse part:

$$
Q=Q_{\mathrm{dir}}+Q_{\mathrm{dif}}=f_{\mathrm{dir}} S \tau \sin \left(h_{\mathrm{s}}+\gamma_{\mathrm{s}}\right)+f_{\mathrm{dif}} S \tau \sin \left(h_{\mathrm{s}}\right),
$$

where $\tau$ is the reduction factor of the incoming solar radiation through the atmosphere. Theoretically, the value of $f_{\text {dif }}$ can vary between 0.15 for clear-sky conditions and 0.85 for overcast conditions, although the latter also depends on the type of cloud (e.g. for a uniform layer of cirrostratus $f_{\text {dif }}$ can be 0.5 (Oerlemans, 2001). Here a constant value of 0.4 is used for $f_{\text {dif, }}$ so the value of $f_{\text {dir }}$ is 0.6 . The model also distinguishes between shaded and non-shaded gridcells. In the case of shade, only the diffuse part of the solar radiation is considered. In the case of no shade, both diffuse and direct radiation are considered. The solar elevation as well as the azimuth is calculated with a standard method (Walraven, 1978). The angle $\left(\gamma_{\mathrm{s}}\right)$ between the sun's projection on the horizontal plane and the plane of the gridcell's slope is calculated as

$$
\gamma_{\mathrm{s}}=\operatorname{atan}[\phi+\cos (a-\theta)] .
$$

\section{CLIMATE FORCING}

In this study, the above-described energy-balance model was applied for two different time periods, using different temperature and precipitation input. At first, detailed data from surrounding weather stations (see Table 2) were used to obtain the surface mass-balance history from 1981 to 2006 in best agreement with the observational data since 2001 . This series of experiments served to calibrate the model and to investigate its basic sensitivity. Results of this calibration run are not presented here (for details see Nemec, 2007), but brought to light how climatic data from surrounding stations
Table 2. Overview of the meteorological data used to force the glacier mass-balance model

Station $\begin{gathered}\text { Measured Time interval Start-end Altitude } \\ \text { variable }\end{gathered}$

$\mathrm{m}$

$\begin{array}{llccc}\text { Samedan Airport } & \text { Air temperature } & 10 \mathrm{~min} & 1981-2006 & 1705 \\ \text { Corvatsch } & \text { Air temperature } & 10 \mathrm{~min} & 1981-2006 & 3315 \\ \text { Pontresina } & \text { Precipitation } & \text { Daily } & 1972-2006 & 1774 \\ \text { Samedan Airport } & \text { Air temperature } & \text { Monthly } & 1864-2005 & 1705 \\ \text { Segl Maria } & \text { Precipitation } & \text { Daily/monthly } & 1864-2005 & 1802\end{array}$

could be treated best to optimally represent temperature and precipitation on the glacier.

For the mass-balance reconstruction between 1865 and 2005 we employed temperature and precipitation data from the HIST-ALP dataset as climate forcing (see Table 2). The HIST-ALP database consists of monthly, homogenized records of temperature, pressure, precipitation, sunshine and cloudiness for the 'Greater Alpine Region' (Auer and others, 2007). The series from Samedan and Segl Maria were selected because those are the stations closest to Vadret da Morteratsch with homogenized long-term records. Daily precipitation and temperature data dating back to 1864 are also available for the Segl Maria station, but these series are not homogenized. Annual mean temperatures calculated from the non-homogenized daily temperatures from Segl Maria appeared to have a bias of up to $0.75^{\circ} \mathrm{C}$ for the period before 1980 when compared to the homogenized annual mean temperatures from Samedan. Likewise, annual precipitation amounts calculated from the homogenized monthly data from Segl Maria differed in a quasi-random way by $240 \mathrm{~mm} \mathrm{a}^{-1}$ from those calculated from the nonhomogenized daily data. This comparison shows the importance of homogenizing long-term climate series and made us favour the monthly data over the more detailed daily data. The homogenized mean summer temperatures from Samedan and annual precipitation sums from Segl Maria are shown in Figure 4.

Finally, using the long-time-series data, the parameters for the surface energy fluxes were slightly retuned. The best agreement between observed and simulated annual balance was found with the following parameters: $c_{0}=-45 \mathrm{~W} \mathrm{~m}^{-2}$, $c_{1}=12 \mathrm{Wm}^{-2}{ }^{\circ} \mathrm{C}^{-1}, \tau=0.45$. These values were found by comparing model results with measurements using the rootmean-square error (RMSE) as a validation criterion (Fig. 5). The comparison was performed between the measurement site and the closest model gridpoint.

\section{Air temperature}

To estimate the surface air temperature and the lapse rate over Vadret da Morteratsch, we used temperature data from Samedan and Corvatsch. Measurements from the IMAU (Instituut voor Marien en Atmosferisch Onderzoek) automatic weather station (AWS) near the tongue of the glacier show that the high-altitude weather station at Corvatsch is best suited to estimate temperature variations on the glacier. The correlation coefficient of daily temperatures at the AWS and Corvatsch for the balance year 1994/95 is very high, 0.97 on an annual basis (Oerlemans, 2001). The Samedan temperature record is less suited for this purpose because 

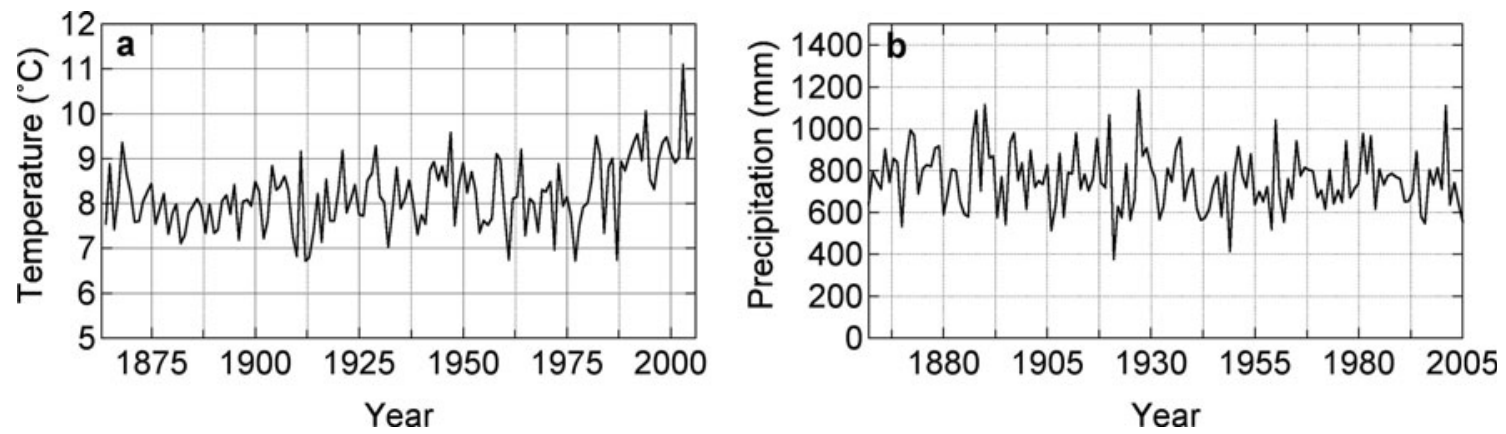

Fig. 4. HIST-ALP climate data used to force the mass-balance model. (a) The homogenized summer temperature (May-September) record from Samedan; (b) the mean annual precipitation sums from Segl Maria. Both records date back to the 1860s.

temperature inversions tend to develop in the valley during the winter. Consequently, when snow is present in the valley, the air temperature in Samedan is often lower than in Corvatsch despite a lower elevation of more than $1600 \mathrm{~m}$. This 'cold pool effect' is not present on the tongue of Vadret da Morteratsch, where a katabatic flow mixes warmer air downwards all the time (Oerlemans, 2001). Therefore the temperature distribution over the glacier was calculated starting from the Corvatsch temperature data. Nevertheless, the Samedan data were taken into account to estimate the mean temperature gradient over the glacier. Daily temperature gradients between Samedan and Corvatsch were calculated for the period 1981-2005. Only values below $-0.006 \mathrm{~K} \mathrm{~m}^{-1}$ were considered because it was assumed that for less negative gradients a temperature inversion was present. This results in a mean temperature gradient of $-0.007 \mathrm{~K} \mathrm{~m}^{-1}$.

To introduce monthly time series, several additional approximations were made. First we found a high correlation $(r=0.978)$ between monthly mean temperature anomalies from Samedan and Corvatsch for the period 1981-2005. This high correlation allows estimation of the mean monthly temperature at Corvatsch, and consequently on the glacier, for the period since 1865 from the long Samedan series using the lapse rate $\gamma_{\mathrm{T}}=-0.007 \mathrm{Km}^{-1}$ established above. The mean daily temperature range on the whole glacier was assumed to be constant at $4^{\circ} \mathrm{C}$, intermediate between the $6^{\circ} \mathrm{C}$ measured at the glacier tongue (Oerlemans, 2000) and the $2^{\circ} \mathrm{C}$ observed at Corvatsch. Therefore, the mean monthly temperature on the glacier and its mean daily cycle were calculated as:

$$
\begin{aligned}
T_{\text {air }} & =\left(\overline{T_{\mathrm{COR}}-T_{\mathrm{SAM}}}\right)_{1981-2005}+T_{\mathrm{SAM}}+\gamma_{\mathrm{T}} \Delta h_{\mathrm{T}} \\
& +T_{\text {amp }} \cos \left(\frac{2 \pi(t-2)}{24}\right)
\end{aligned}
$$

where $\Delta h_{\mathrm{T}}$ is the altitude difference with respect to Corvatsch. $T_{\text {air }}$ is used for the calculation of the turbulent and longwave fluxes. For the threshold temperature of snow, the monthly mean temperature plus the altitudinal gradient was used.

\section{Precipitation}

The distribution of precipitation on the glacier is more complicated to handle than air temperature. Precipitation amounts in mountainous regions are spatially non-uniform and have a strong vertical dependence. Sites only a few kilometres away may receive significantly different amounts. Beside that, there are limited precipitation data available at higher elevations. For conditions high up in the accumulation zone of Vadret da Morteratsch, the ice-core measurements from Piz Zupo at 3900 ma.s.l. are believed to be the most representative. Correlations were sought between these data and data from the valley stations, for the period between 1 October and 30 September of the following year, in order to be able to compare balance years. For the period 1991-2001 the mean vertical precipitation gradient between Piz Zupo and two valley stations varies from between $0.90 \mathrm{~mm}$ w.e. $\mathrm{m}^{-1}$ with respect to Pontresina, and $0.97 \mathrm{~mm}$ w.e. $\mathrm{m}^{-1}$ with respect to Segl Maria. Interestingly, the mean vertical precipitation gradient between Corvatsch $(3315 \mathrm{~m})$ and Pontresina $(1774 \mathrm{~m})$ is only $0.05 \mathrm{~mm}$ w.e. $\mathrm{m}^{-1}$, and for some years the gradient is even negative. The reason might be an undercatchment of precipitation at the weather station on Corvatsch due to high wind speeds. We adapted a value of $\gamma_{P}=1.0 \mathrm{~mm}$ w.e. $\mathrm{m}^{-1}$, as this gives the best fit with the observed annual balance data. This value is significantly higher than the precipitation gradient of $0.4-0.5 \mathrm{~mm}$ w.e. $\mathrm{m}^{-1}$ used by Klok and Oerlemans (2002) and Oerlemans and Klok (2004) and the value of $0.8 \mathrm{~mm}$ w.e. $\mathrm{m}^{-1}$ in Machguth (2003). The higher gradient found here might also be due to the fact that the ice-core measurement site is believed to be located in a sink area for snow blowing from across the ridge onto the glacier. From the available data we are not able to make a further differentiation of the precipitation rate with respect to wind exposure and elevation. For instance, it is known from some other high mountain glaciers in the Alps that a precipitation maximum occurs at around 3500 ma.s.l., which is lower than the highest summits in our study area.

In order to apply the monthly precipitation series from Segl Maria since 1865 we calculated the ratio of mean monthly precipitation at Pontresina and Segl Maria for the overlapping period 1972-2005 and multiplied this by the monthly precipitation at Segl Maria for the whole period (1865-2005). For the period 1972-2005 the correlation coefficient $(r)$ between the calculated and the observed monthly precipitation at Pontresina is 0.87 , not as high as for the temperature series but still acceptable for our purpose. This gives the following relation to estimate monthly precipitation sums on the glacier:

$$
P=P_{\mathrm{SEG}}\left(\frac{\overline{P_{\mathrm{PON}}}}{\overline{P_{\mathrm{SEG}}}}\right)_{1972-2005}+\gamma_{\mathrm{P}} \Delta h_{\mathrm{P}}
$$

where $\Delta h_{\mathrm{P}}$ is the altitude difference with respect to Pontresina. 
The initial calibration for the period 1981-2006 using the daily precipitation data from Pontresina brought to light the large sensitivity of the net mass balance to the frequency and intensity of the precipitation events in the course of any month. The timing of the precipitation events was therefore taken from the non-homogenized daily precipitation series from Segl Maria after scaling for the mismatches of the associated monthly sums to the homogenized precipitation series from the same station. This is believed to be the best option available. Nevertheless, combining daily precipitation input with mean monthly air temperature to distinguish between snow and rain might lead to an underestimation of snowfall events, especially in the summer months. Summer snowfall episodes are known to have a large impact on the net mass balance of a glacier, due to the dependence of the albedo on snow depth (Oerlemans and Klok, 2004). Furthermore, the precipitation on Morteratsch is ultimately estimated from stations located in different valleys, even though the distance between the stations is not very large. These considerations suggest that the precipitation treatment is likely to be the largest source of uncertainty in the calculation of the net mass balance of Vadret da Morteratsch.

\section{RESULTS}

Figure 5 shows the modeled mass balance compared to the stake observations over five balance years between 2001 and 2005. The agreement is best for the balance year 2003/ 04, with a RMSE of $0.43 \mathrm{~m}$ w.e. $\mathrm{a}^{-1}$. The other three years have a somewhat larger RMSE between 0.53 and $1.07 \mathrm{~m}$ w.e. $\mathrm{a}^{-1}$. The largest discrepancies can be found in the lower part of the glacier, especially in the warmer years. This may be explained by simplifications in the albedo parameterization and in the parameterization of the longwave and turbulent energy fluxes. In the model, the ice albedo remains constant during the ablation period. In reality, however, the bare glacier surface may be covered with dirt after a longer period without snowfall, which decreases the albedo and consequently increases the amount of energy absorbed by the surface. Also the parameterization of the longwave and turbulent fluxes may cause an underestimation of melt at lower altitudes because in the model these fluxes depend only on air temperature. For example, near the glacier snout the valley is rather narrow. Longwave radiation from the valley walls that heat up during the day is not included in the parameterization. Also the humidity profile above the glacier surface is not explicitly included in the calculation of the turbulent fluxes, mainly because such data are not available for the whole period from stations in the proximity of the glacier. Finally, part of the underestimation can also be explained by using a fixed surface elevation distribution valid for the year 1998. The lowest part of the glacier is known to be almost stagnant (hardly any horizontal flow), and the surface elevation therefore lowers by about the ablation rate of up to $10 \mathrm{~m} \mathrm{a}^{-1}$. Between 1998 and 2005 one could expect a lowering of the glacier tongue by $50-60 \mathrm{~m}$. Assuming a mass-balance gradient of $1 \mathrm{~m}$ w.e. $(100 \mathrm{~m})^{-1}$, this already explains an underestimation of around $0.5 \mathrm{~m}$ w.e. for the lowest ablation stake by the end of the calibration period.

The model also does not capture the full effect of the shading. This can be clearly seen, for example, in 2003/04
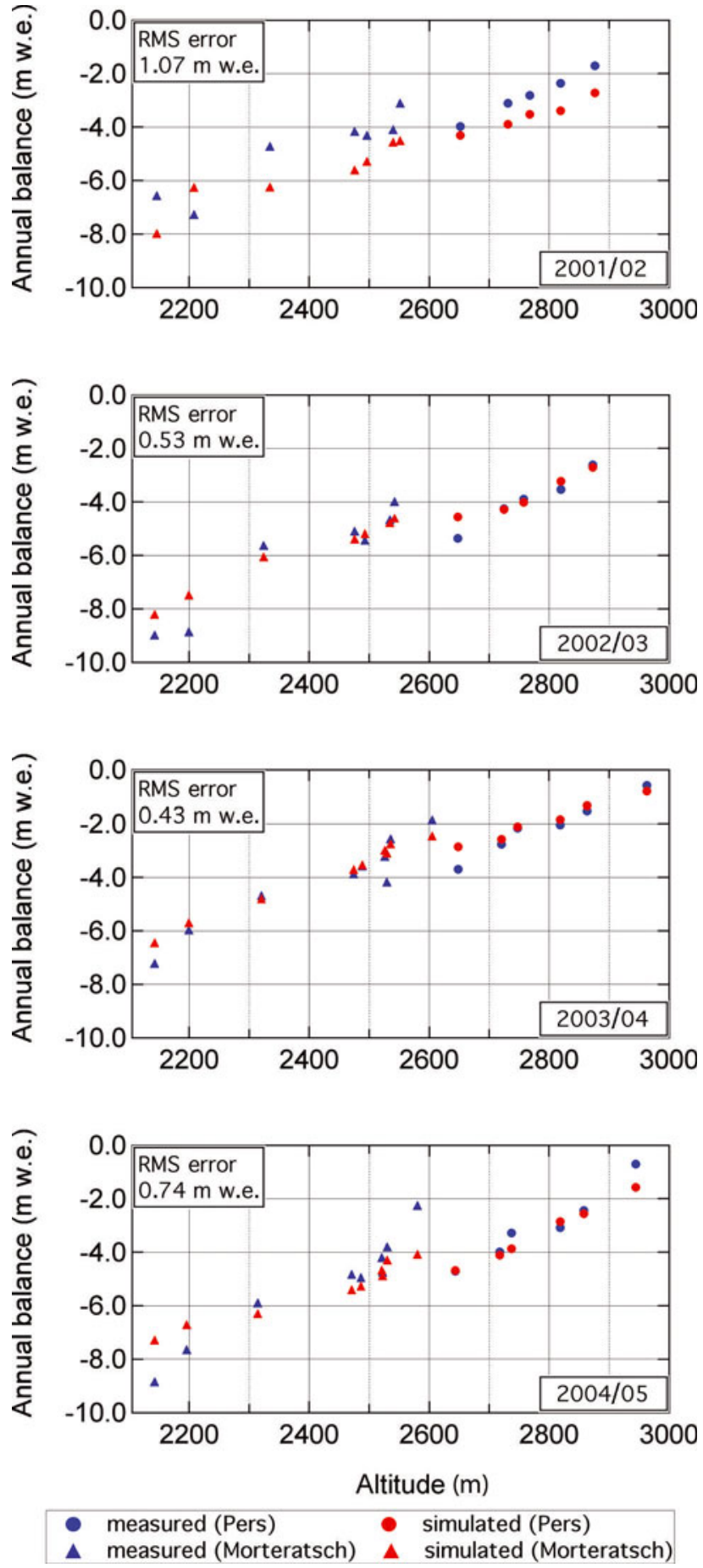

Fig. 5. Comparison of simulated and measured mass balance for four balance years 2002-05. The RMSE is also shown.

and 2004/05 for the highest measurements on Vadret da Morteratsch along the cross-profile at $2550 \mathrm{~m}$ a.s.l. and for the stake at 2650 ma.s.I. on Vadret Pers. Here, the model shows less contrast than the observations. However, we also note that a fraction of the mismatches between model and observations is likely due to the inherent variability in the measurements from the random stake position.

Finally we used the model to reconstruct the mean annual balance of the whole glacier (specific mass balance) for the period 1865-2005 using the long climate records from Samedan and Segl Maria. To do this properly, it is important to take into account the major effect of the change of glacier geometry over this period. Since 1865 the 


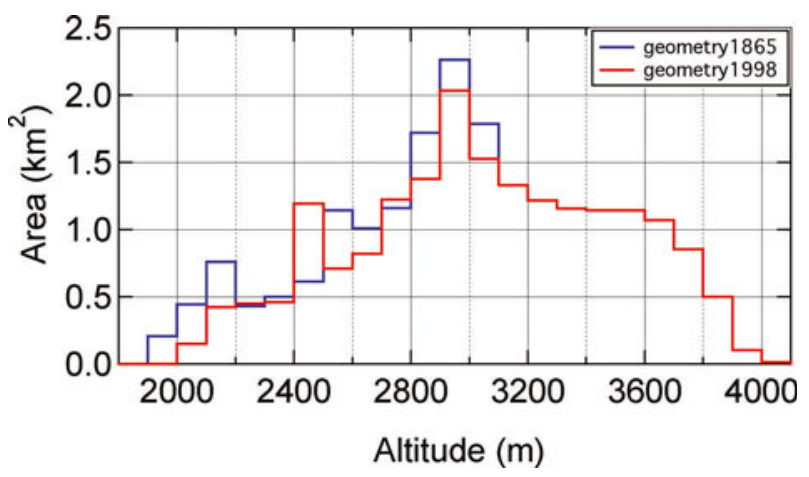

Fig. 6. Area-elevation distribution of Vadret da Morteratsch as adopted for the years 1865 (blue) and 1998 (red).

glacier lost more than $2 \mathrm{~km}$ of its tongue, concomitant with a thinning at the snout of up to $200 \mathrm{~m}$. We addressed this problem by first running the mass-balance model for both end members of the glacier's size and elevation. The recent glacier geometry corresponds to the year 1998 as provided directly by the DEM of the Bundesamt für Landestopographie, Switzerland. Additionally, we reconstructed the 1865 glacier geometry from the known maximum extent of the glacier (Glaciological reports, 1881-2007; Maisch and others, 1999) and the height of the trimlines in the ablation area as inferred from the topographical map. We have no data that support significant geometry changes in the accumulation area of the glacier. The area-elevation distribution for both geometries is shown in Figure 6. If we assume that the retreat of the glacier was regular, and the length record indeed suggests an approximately linear retreat, then the actual specific mass balance between 1865 and 2005 can to a good approximation be found by a gradual linear interpolation between the specific massbalance simulations for the two glacier geometries between 1865 and 1998, and a further linear extrapolation for the period up to 2005. Both curves for the simulated specific mass balance for the two geometries broadly show the same behaviour, with a mean difference of 0.27 mw.e. Years with a more negative specific mass balance show slightly larger deviations, which can be explained by the larger ablation area in geometry1865 and the non-linear dependence of the melting on elevation (higher temperatures cause higher melting and a shorter period with snow cover). The interpolated specific mass balance is shown in Figure 7a. Nevertheless, the cumulative mass balances for geometry1865 and geometry1998 show quite large differences (Fig. 7b). While the cumulative mass balance is negative from 1865 onwards with geometry1865, it is around zero for geometry1998 until approximately 1920 . At the end of the reconstruction period the cumulative mass balance for geometry 1998 is $-28 \mathrm{mw}$.e. and for geometry1865 it is $-67 \mathrm{~m}$ w.e. A gradual linear interpolation/ extrapolation between the two results gives a cumulative specific mass balance of $-46 \mathrm{mw}$.e., or a mean glacier thinning of about $51 \mathrm{~m}$ ice equivalent between 1865 and 2005. Incidentally, this mass loss is in very good agreement with the volume change divided by the mean glacier area of $-44 \mathrm{~m}$ w.e. inferred directly from the two geometries for the slightly shorter period 1865-1998.

In most of the years the interpolated specific mass balance is negative; only in $25 \%$ of the years (35 out of 141 ) was it positive. A trend towards a more negative mass balance can also be observed in the last two decades, starting approximately in 1980. Between 1970 and 1980, several years even had a positive specific mass balance. Before this period, the specific mass balance is negative in almost every year back to 1920, with a period of increased mass loss between 1940 and 1950. The cumulative mass balance shows only a few periods with a rising trend, most importantly between 1911 and 1920 when the glacier gained about $2 \mathrm{mw}$.e. During the last 25 years of the simulation, the cumulative mass balance was $-16 \mathrm{~m}$ w.e., which represents $33 \%$ of the total mass loss of the last 141 years.

Similar features were obtained for other Alpine glaciers. For the period 1935-77, our results have a correlation coefficient of 0.88 with Aletschgletscher and 0.75 with Hintereisferner, for which specific mass balances were calculated with the hydrological method (Steinacker, 1979). For all three glaciers, the most negative mass balances during this period occurred between 1940 and 1950. In a recent publication, the mass balances of Aletsch, Rhone, Gries and Silvretta glaciers were reconstructed for the period 1865-2006 using a temperature-index model (Huss and others, 2008). The results show regional differences between the four glaciers, but the pattern of ice loss is very similar to ours, with two periods of zero or slightly positive mass balance (1912-20 and 1974-81) and two periods with enhanced mass loss (1942-50 and 1998-2006).

\section{CONCLUSIONS}

The reconstructed mass loss of Vadret da Morteratsch between 1865 and 2005 is found to be approximately $46 \mathrm{~m}$ w.e. This value is in good agreement with the volume change of $44 \mathrm{~m}$ inferred from the glacier geometries used for the reconstruction. The cumulative specific mass balance over this period shows an almost continuous mass loss, with short periods of mass gain around 1920, 1935 and 1980. After 1980 a trend towards a more negative mass balance is found. The decreasing specific mass balance is mainly associated with increasing summer temperature. A slight trend towards less precipitation can, however, be observed during the last 10 years. This trend is more obvious in the snow accumulation since snow accumulation decreases when temperature increases. In addition, the high annual variability in the specific balance appears most influenced by snow accumulation.

The comparison between the measured and the calculated annual balance shows a relatively good agreement. The largest discrepancies can be found in the lowest part of the glacier. The reason for this is the use of constant 1998 geometry and simplifications in the parameterization of the longwave and turbulent energy fluxes that in the model depend only on the air temperature. As especially the latent turbulent heat flux depends to a large extent on the humidity content of the air above the glacier surface, including the humidity could make a great improvement. This could be done, for example, by replacing the air temperature (Equation (2)) by the wet-bulb temperature or by the equivalent potential temperature (the temperature a parcel of air would reach if all the water vapour in the parcel were to condense, releasing its latent heat, and the parcel was brought adiabatically to a pressure of $1000 \mathrm{hPa}$ ), which both include humidity. Finally, we would like to point out that even 

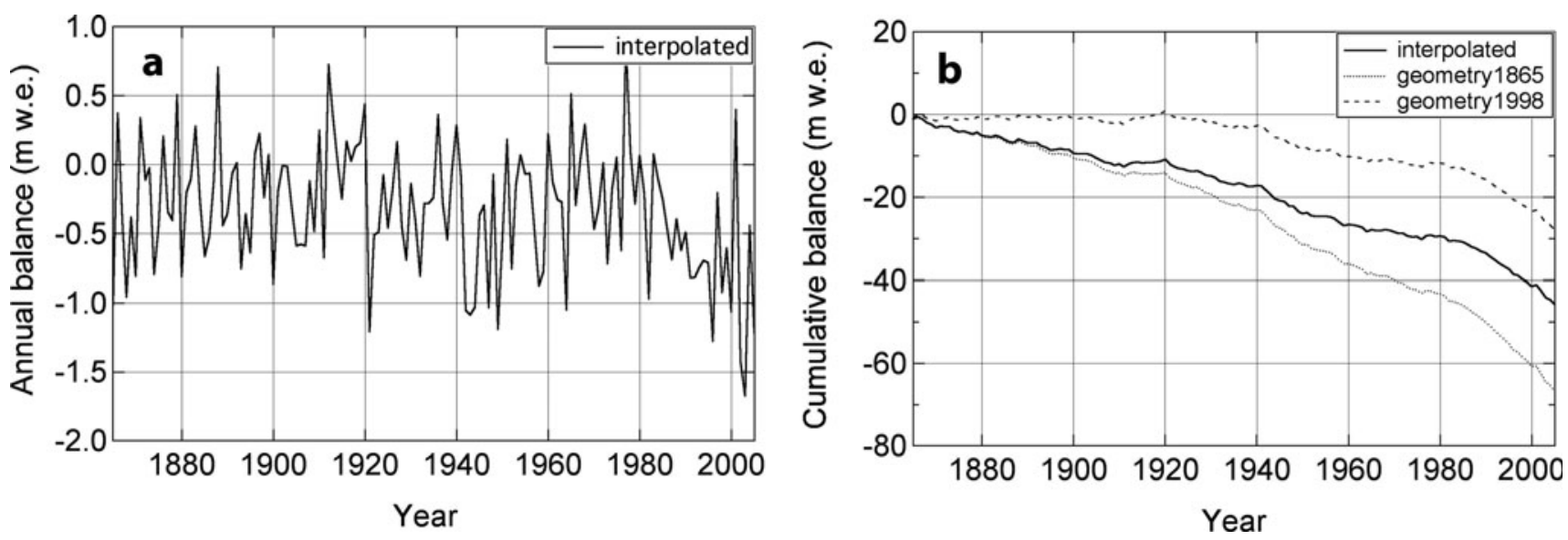

Fig. 7. (a) Interpolated annual mass balances for the period 1865-2005; (b) cumulative mass balance (with geometry1998, geometry1865 and interpolated) for the period 1865-2005.

though the glacier model provides a realistic output compared to mass balances of other glaciers as well as compared to the measurements, many aspects can still be improved. However, the model already seems capable of long-term calculations of mass balance as well as of driving a glaciological flow model to reconstruct the ice dynamics of the glacier retreat.

\section{ACKNOWLEDGEMENTS}

We thank everyone who took part in the fieldwork on Vadret da Morteratsch. We also thank A. Palmer (Paul Scherrer Institut, Villigen, Switzerland) for providing the Piz Zupo ice-core dataset, as well as MeteoSwiss and Zentralanstalt für Meteorologie und Geophysik (ZAMG) for providing the climate data. Comments and suggestions from A. Bauder and an anonymous reviewer greatly helped to improve the manuscript. Financial support was provided through the German HGF-Strategiefonds Projekt 'SEAL', the Belgian Science Policy Office programme 'Science for a Sustainable Development', and the EU FP6 Marie Curie Research Training Network 'NICE'.

\section{REFERENCES}

Anonymous. 1969. Mass-balance terms. J. Glaciol., 8(52), 3-7.

Auer, I. and 31 others. 2007. HISTALP - historical instrumental climatological surface time series of the Greater Alpine Region. Int. J. Climatol., 27(1), 17-46.

Dyurgerov, M.B. and M.F. Meier. 2005. Glaciers and the changing Earth system: a 2004 snapshot. Boulder, CO, University of Colorado. Institute of Arctic and Alpine Research. (INSTAAR Occasional Paper 58.)

Glaciological reports. 1881-2008. The Swiss glaciers, 1880-2002/ 03, Yearbooks of the Cryospheric Commission of the Swiss Academy of Sciences (SCNAT), 1-124. Published since 1964 by VAW-ETHZ. Zürich.

Greene, A.M. 2005. A time constant for hemispheric glacier mass balance. J. Glaciol., 51(174), 353-362.

Greene, A., W.S. Broecker and D. Rind. 1999. Swiss glacier recession since the Little Ice Age: reconciliation with climate records. Geophys. Res. Lett., 26(13), 1909-1911.

Hock, R. 2005. Glacier melt: a review on processes and their modelling. Progr. Phys. Geogr., 29(3), 362-391.
Huss, M., A. Bauder, M. Funk and R. Hock. 2008. Determination of the seasonal mass balance of four Alpine glaciers since 1865. J. Geophys. Res., 113(F1), F01015. (10.1029/2007JF000803.)

Klok, E.J. 2004. Modelled climate sensitivity of the mass balance of Morteratschgletscher and its dependence on albedo parameterization. Int. J. Climatol., 24(2), 231-245.

Klok, E.J. and J. Oerlemans. 2002. Model study of the spatial distribution of the energy and mass balance of Morteratschgletscher, Switzerland. J. Glaciol., 48(163), 505-518.

Lemke, P. and 10 others. 2007. Observations: changes in snow, ice and frozen ground. In Solomon, S. and 7 others, eds. Climate change 2007: the physical science basis. Contribution of Working Group I to the Fourth Assessment Report of the Intergovernmental Panel on Climate Change. Cambridge, etc., Cambridge University Press, 337-383.

Machguth, H. 2003. Messung und dreidimensionale Modellierung der Massenbilanzverteilung auf Gletschern der Schweizer Alpen. (MSc thesis, Universität Zürich.)

Machguth, H., F. Paul, M. Hoelzle and W. Haeberli. 2006. Distributed glacier mass-balance modelling as an important component of modern multi-level glacier monitoring. Ann. Glaciol., 43, 335-343.

Maisch, M., C.A. Burga and P. Fitze. 1999. Lebendiges Gletschervorfeld: von schwindenden Eisströmen, schuttreichen Moränenwällen und wagemutigen Pionierplflanzen im Vorfeld des Morteratschgletschers. Samedan, Engadin Press.

Nemec, J. 2007. Reconstruction of the surface mass balance of Morteratschgletscher since 1865. (MSc thesis, University of Vienna.)

Oerlemans, J. 2000. Analysis of a 3 year meteorological record from the ablation zone of Morteratschgletscher, Switzerland: energy and mass balance. J. Glaciol., 46(155), 571-579.

Oerlemans, J. 2001. Glaciers and climate change. Lisse, etc., A.A. Balkema.

Oerlemans, J. and E.J. Klok. 2004. Effect of summer snowfall on glacier mass balance. Ann. Glaciol., 38, 97-100.

Oerlemans, J. and W.H. Knap. 1998. A 1 year record of global radiation and albedo in the ablation zone of Morteratschgletscher, Switzerland. J. Glaciol., 44(147), 231-238.

Palmer, A.S., M. Schwikowski and H.W. Gaeggeler. 2003. A subseasonal trace chemical ice core record from Piz Zupo, Swiss Alps. Geophys. Res. Abstr. 5, 01331.

Paterson, W.S.B. 1994. The physics of glaciers. Third edition. Oxford, etc., Elsevier.

Paul, F., A. Kääb and W. Haeberli. 2007. Recent glacier changes in the Alps observed from satellite: consequences for future monitoring strategies. Global Planet. Change, 56(1-2), 111-122. 
Raper, S.C.B. and R.J. Braithwaite. 2005. The potential for sea level rise: new estimates from glacier and ice cap area and volume distributions. Geophys. Res. Lett., 32(5), L05502. (10.1029/ 2004GL021981.)

Schöner, W. and R. Böhm. 2007. A statistical mass-balance model for reconstruction of LIA ice mass for glaciers in the European Alps. Ann. Glaciol., 46, 161-169.

Steinacker, R. 1979. Rückrechnung des Massenhaushaltes des Hintereisferners mit Hilfe von Klimadaten. Z. Gletscherkd. Glazialgeol., 15(1), 101-104.
Vincent, C. 2002. Influence of climate change over the 20th century on four French glacier mass balances. J. Geophys. Res., 107(D19), 4375. (10.1029/2001JD000832.)

Vincent, C., E. Le Meur, D. Six and M. Funk. 2005. Solving the paradox of the end of the Little Ice Age in the Alps. Geophys. Res. Lett., 32(9), L09706. (10.1029/2005GL022552.)

Walraven, R. 1978. Calculating the position of the Sun. Solar Energy, 20(5), 393-397.

Zemp, M., W. Haeberli, M. Hoelzle and F. Paul. 2006. Alpine glaciers to disappear within decades? Geophys. Res. Lett., 33(13), L13504. (10.1029/2006GL026319.) 